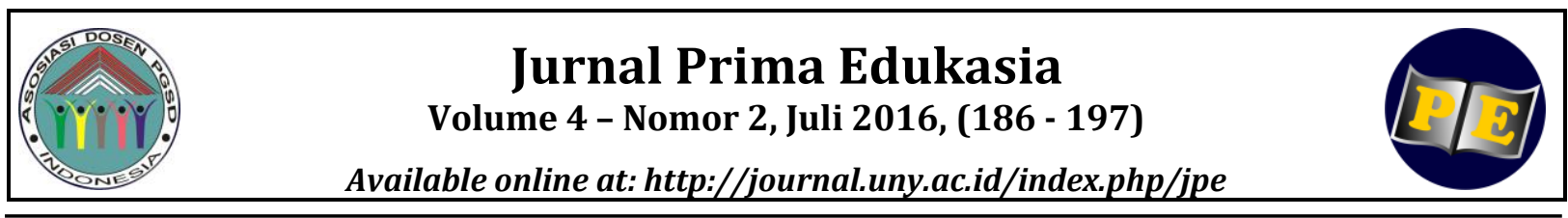

\title{
PENGARUH PBL TERHADAP KETERAMPILAN PROSES SAINS DAN HASIL BELAJAR KOGNITIF IPA PADA SISWA SD
}

\author{
Ratna Hidayah ${ }^{1)}$, Pratiwi Pujiastuti ${ }^{2)}$ \\ ${ }^{1}$ SD Negeri Kotagede 5. Jalan Kemasan, No. 68, Prenggan Kota Gede, 55172, Indonesia \\ ${ }^{2}$ Pendidikan Sekolah Dasar, Universitas Negeri Yogyakarta. Jalan Colombo No.1 Karangmalang, \\ Yogyakarta 55281, Indonesia. \\ Email: ${ }^{1}$ ratnahidayah@ hotmail.com, ${ }^{2}$ pratiwi@uny.ac.id
}

\begin{abstract}
Abstrak
Penelitian ini bertujuan untuk mengetahui: (1) pengaruh PBL terhadap keterampilan proses sains; (2) pengaruh PBL terhadap hasil belajar kognitif IPA; (3) pengaruh PBL terhadap keterampilan proses sains dan hasil belajar kognitif IPA secara bersama-sama. Penelitian ini merupakan penelitian eksperimen semu dengan pretest-postest control group design. Populasi dalam penelitian ini adalah seluruh kelas V SD Gugus 3 Kotagede Yogyakarta tahun pelajaran 2014/ 2015. Pengambilan sampel menggunakan teknik Cluster Random Sampling. Data dianalisis dengan independent t-test, uji MANOVA, dan uji kriteria Bonferroni. Hasil penelitian menunjukkan bahwa: Hasil penelitian menunjukkan bahwa: (1) PBL berpengaruh positif dan signifikan terhadap keterampilan proses sains; (2) PBL berpengaruh positif dan signifikan terhadap hasil belajar IPA. (3) PBL berpengaruh positif dan signifikan terhadap keterampilan proses sains dan hasil belajar IPA. Keterampilan proses sains dan hasil belajar kognitif IPA di kelas eksperimen 1 dan kelas eksperimen 2 lebih tinggi daripada kelas kontrol. Keseluruhan uji dan hasil penelitian ini menunjukkan bahwa PBL berpengaruh positif dan signifikan terhadap keterampilan proses sains dan hasil belajar kognitif IPA.
\end{abstract}

Kata Kunci: problem based learning, keterampilan proses sains, hasil belajar kognitif sains

\section{THE EFFECT PBL ON SCIENCE PROCESS SKILL AND COGNITIVE LEARNING RESULT OF SCIENCE TO STUDENTS OF ELEMENTARY SCHOOL}

\begin{abstract}
This research is aimed to get information about: (1) the effect of PBL on science process skills; (2) the effect of PBL on the result of cognitive-learning of science and (3) the effect of PBL on science process skill and the result of cognitive-learning of science. This is quasi experiment research employing a pretest-posttest control group design. The research population consisted of five-graders of all elementary schools located in Group 3 of Kotagede in the academic year of 2014/2015. The sample was collected using the cluster random sampling technique. The data were analyzed using the independent $t$-test, the MANOVA, and Bonferroni criterion. The result of this research informs that: (1) PBL improved positively and significantly the science process skills; (2) PBL improved positively and significantly science learning result; (3) PBL improved positively and significantly the science process skills and science learning result. The skills of science process and cognitive result of learning of science of the experiment class 1 and 2 are higher than that of the control class. The whole tests and gained results show that PBL positively and significantly improves the skills of science process and the cognitive result of science learning.
\end{abstract}

Keywords: problem based learning, skills of science process, cognitive learning result of science.

How to Cite: Hidayah, R., \& Pujiastuti, P. (2016). Pengaruh PBL terhadap keterampilan proses sains dan hasil belajar kognitif IPA pada siswa SD. Jurnal Prima Edukasia, 4(2), 186-197. doi:http://dx.doi.org/10.21831/jpe.v4i2.7789

Permalink/DOI: http://dx.doi.org/10.21831/jpe.v4i2.7789 
Jurnal Prima Edukasia, 4 (2), Juli 2016 - 187

Ratna Hidayah, Pratiwi Pujiastuti

\section{Pendahuluan}

Pendidikan merupakan proses peningkatan kualitas sumber daya manusia. Melalui pendidikan, manusia dapat menemukan hal-hal baru yang dapat mengembangkan sikap, keterampilan dan intelektualnya. Pemerintah mengupayakan kebijakan dalam upaya meningkatkan mutu pendidikan terus dilaksanakan antara lain melalui pembaharuan kurikulum berupa Kurikulum Tingkat Satuan Pendidikan. Kegiatan pembelajaran merupakan komponen penting dalam proses pendidikan. Kegiatan pembelajaran merupakan suatu kegiatan melaksanakan kurikulum suatu lembaga pendidikan, agar dapat mempengaruhi siswa untuk mencapai tujuan pendidikan yang telah ditetapkan. Pembelajaran di lembaga pendidikan juga dapat dimaksudkan dengan proses reproduksi nilai dan budaya dilakukan dengan mediasi proses belajar mengajar sejumlah mata pelajaran di kelas. Salah satu mata pelajaran yang turut berperan penting dalam pendidikan sikap, pengetahuan dan keterampilan sejak dini bagi anak adalah IPA.

Mata pelajaran IPA merupakan salah satu dasar ilmu pengetahuan yang berkembang dan juga menjadi tumpuan bagi perkembangan IPTEK. Sumber daya manusia yang handal dan mampu bersaing secara global diperlukan untuk menghadapi tantangan perkembangan IPTEK. Pembelajaran IPA tidak hanya menekankan pada pemahaman konsep saja tetapi perlu diterapkan kegiatan-kegiatan agar siswa mampu menemukan pengetahuan atau konsep sendiri melalui pengalamannya sendiri dengan cara melakukan pengamatan, percobaan dan diskusi tentang gejala alam serta memecahkan suatu permasalahan sehingga dapat dikatakan sebagai pembelajaran bermakna.

Keterampilan proses sains perlu untuk dikembangkan dalam dunia pendidikan. Keterampilan proses sains dapat sebagai kompetensi dasar untuk mengembangkan sikap ilmiah dan keterampilan dalam memecahkan masalah, sehingga dapat membentuk pribadi siswa yang kreatif, kritis, terbuka, inovatif, dan kompetitif. Pengoptimalan keterampilan proses sains dalam proses pembelajaran, untuk meningkatkan keberhasilan belajar siswa. Keterampilan proses sains yang dimiliki oleh siswa akan menjadi bekal dalam menghadapi permasalahan yang ada dalam kehidupan sehari-hari, karena terbiasa melakukan proses sains dalam pemecahan masalah. Proses pembelajaran yang melibatkan siswa aktif sebagai subjek belajar, dengan melakukan kegiatan proses sains yang akan membuat materi pelajaran mudah dipahami dan diingat dalam waktu yang relatif lama sehingga dapat pula memberikan pengaruh terhadap hasil belajar kognitif siswa.

Hasil belajar kognitif merupakan kemampuan yang diperoleh siswa setelah melalui kegiatan belajar. Umumnya, pengukuran suksesnya pembelajaran dilihat dari hasilnya. Siswa yang berhasil dalam belajar ialah yang berhasil mencapai tujuan-tujuan pembelajaran. Proses belajar mengajar dianggap berhasil apabila daya serap terhadap materi pelajaran yang diajarkan mencapai prestasi tinggi, baik secara individu maupun kelompok, dan perilaku yang digariskan dalam tujuan pengajaran telah dicapai siswa, baik secara individu maupun kelompok.

Guru merupakan salah satu faktor penting yang dapat menentukan berhasil atau tidaknya siswa dalam belajar IPA. Peran guru dalam pendidikan tidak terlepas dari kemampuan guru dalam menyampaikan materi pada siswa. Kemampuan guru sebagai salah satu usaha meningkatkan mutu pendidikan yaitu dengan menerapkan model pembelajaran yang tepat dan bervariasi.

Berdasarkan observasi peneliti di kelas $\mathrm{V}$ SD Gugus 3 Kotagede pada tanggal 18-21 Agustus 2014, terlihat guru masih mendominasi pembelajaran (teacher centered) dengan menggunakan model ekspositori. Model ini hanya berhasil diterima baik oleh siswa yang memliki perhatian yang lebih dan kemampuan menyimak dengan baik. Model ekspositori ini sangat bergantung dengan kemampuan guru seperti, pengelolaan kelas dan penyampaian materi. Model ekspositori yang digunakan guru didominasi metode ceramah sehingga dinilai kurang mengembangkan kemampuan siswa dalam bersosialisasi, keterampilan penelitian dan berpikir ilmiah. Selama ini guru tidak tahu dengan jenis model pembelajaran yang diterapkan, yang terpenting bagi mereka adalah bagaimana siswa dapat terkondisi selama pembelajaran dan semua materi dapat tersampaikan ke siswa. Pelaksanaan pembelajaran yang terdapat kompetensi IPA masih kurang belum memperhatikan keterampilan proses sains dan hasil belajar kognitif IPA. Guru mengatakan bahwa penilaian untuk keterampilan proses sains jarang dilakukan karena kendala kurangnya waktu. Waktu adalah 
Jurnal Prima Edukasia, 4 (2), Juli 2016 - 188

Ratna Hidayah, Pratiwi Pujiastuti

alasan utama tidak mengembangkan keterampilan proses sains siswa, yang berdampak pada hasil belajar kognitif siswa yang kurang optimal. Kurang optimalnya hasil belajar kognitif terlihat saat diberikan soal evaluasi. Siswa merasa kesulitan dan bingung dalam mengerjakan soal. Pemahaman peserta didik terhadap konsep-konsep IPA belum maksimal dilihat ratarata nilai Ulangan Tengah Semester (UTS) untuk muatan IPA pada kelas V masih 72 dan rata- rata nilai ulangan harian pada materi Gaya pada bulan Januari yang mencapai nilai 69 .

Keterampilan proses sains perlu dilatih agar siswa menjadi terampil dalam memperoleh dan mengkaji berbagai informasi mengenai fenomena alam dalam kehidupan sehari- hari. Guru diharapkan dapat memberikan kesempatan yang cukup kepada siswa untuk belajar melalui pemecahan masalah. Salah satu penyebab keterampilan proses sains dan hasil belajar siswa belum maksimal yaitu guru kurang bervariasi dalam penggunaan model pembelajaran.

Guru membutuhkan model pembelajaran yang menekankan pada proses pencarian pengetahuan dari pada transfer pengetahuan. Siswa dipandang sebagai subjek belajar yang perlu dilibatkan secara aktif dalam proses pembelajaran, guru sebagai seorang fasilitator yang membimbing dan mengkoordinasikan kegiatan belajar sehingga guru tidak hanya mengajar tapi membelajarkan. Salah satu model pembelajaran yang dapat dilaksanakan di kelas yaitu model problem based learning. Pada dasarnya model pembelajaran ini lebih menekankan bahwa siswa tidak disajikan dengan pelajaran dalam bentuk finalnya, tetapi diharapkan mengorganisasi sendiri. Massa (2008, p.19) mengungkapkan bahwa pembelajaran berbasis masalah tidak seperti pembelajaran tradisional yang mana informasi ditransfer secara pasif dari guru ke siswa, dalam pembelajaran berbasis masalah siswa aktif berpartisipasi dalam proses belajar mereka sendiri yang mengantarkan siswa ke situasi yang membingungkan, yang mana standar penyelesaiannya kurang jelas dan membingungkan seperti masalah dalam dunia nyata. Dalam hal ini, siswa secara aktif membangun pengetahuan yang dibutuhkan dari masalah yang diberikan. Peran aktif siswa dalam proses belajar mengindikasikan bahwa belajar berbasis masalah bukan transfer ilmu dari guru ke siswa tetapi guru sebagai fasilisator yang menyediakan masalah dan mediator yang dibutuhkan oleh siswa untuk mengkontruksi pengetahuannya sendiri. Dengan demikian masalah yang disajikan dalam pembelajaran diharapkan dapat memberikan pengaruh terhadap siswa dalam memahami konsep yang diberikan problem based learning sehingga membantu siswa dalam mengembangkan keterampilan proses sains dan pengetahuan.

IPA sangat erat dengan model pembelajaran yang berbasis masalah. Hal ini karena IPA adalah pelajaran yang mempelajari hal- hal yang berhubungan dalam dunia nyata. Problem based learning merupakan model pembelajaran yang lebih menekankan pada pemecahan masalah atau masalah dalam kehidupan nyata sebagai titik tolaknya. Adanya suatu masalah, siswa merasa tertantang untuk bereksplorasi mengumpulkan dan menganalisis data untuk memecahkan suatu masalah lalu menemukan solusinya. Langkah-langkah pembelajaran dalam problem based learning diasumsikan dapat membantu siswa dalam mengembangkan penguasaan yang mendalam tentang keterampilan proses sains dan hasil belajar kognitif siswa.

Penelitian dilaksanakan di SD Gugus 3 Kotagede kelas V, alasan peneliti melaksanakan penelitian di gugus tersebut karena di kelas $\mathrm{V}$ SD Gugus 3 Kotagede penggunaan model pembelajaran belum bervariasi yaitu masih menggunakan pembelajaran ekspositori, aspek keterampilan siswa dan hasil belajar kognitif IPA belum optimal. Belum diketahuinya pengaruh model problem based learning terhadap keterampilan proses sains dan hasil belajar kognitif IPA.

Tujuan penelitian ini yaitu untuk mengetahui (1) pengaruh model problem based learning terhadap keterampilan proses sains siswa kelas V SD Gugus 3 Kotagede; (2) Pengaruh model problem based learning terhadap hasil belajar kognitif IPA siswa kelas V SD Gugus 3 Kotagede; (3) Pengaruh model problem based learning terhadap keterampilan proses sains dan hasil belajar kognitif IPA secara bersama-sama pada pembelajaran IPA Siswa Kelas V SD Gugus 3 Kotagede.

Adapun manfaat penelitian meliputi manfaat teoritis dan manfaat praktis. Manfaat teoritis dijadikan sebagai bahan kajian bagi peneliti lain yang ingin melakukan penelitian yang berhubungan dengan model pembelajaran problem based learning, keterampilan proses sains dan hasil belajar kognitif pada pembel- 
Jurnal Prima Edukasia, 4 (2), Juli 2016 - 189

Ratna Hidayah, Pratiwi Pujiastuti

ajaran IPA. Manfaat praktik yaitu bagi siswa, memberikan pengalaman belajar yang berbeda sehingga dapat meningkatkan keterampilan proses sains dan hasil belajar kognitif IPA. Bagi guru sebagai bahan pertimbangan dalam memilih dan mengembangkan model pembelajaran yang digunakan di kelas. Bagi sekolah, hasil penelitian memberikan sumbangan yang berharga dalam rangka perbaikan sistem pembelajaran sekolah.

\section{Metode}

Jenis Penelitian

Penelitian ini menggunakan pendekatan kuantitatif dengan jenis penelitian eksperimen semu, dengan desain Pretest posttest control group design

Waktu dan Tempat Penelitian

Penelitian ini dilaksanakan di 3 kelas dari 3 sekolah di SD Gugus 3 Kotagede Yogyakarta yaitu SDN Kotagede 5, Kelas A SDN Kotagede 1, dan SDN Baluwarti Waktu penelitian dilakukan pada semester II Tahun ajaran 2014/2015.

Populasi /Sampel

Populasi dalam penelitian ini adalah seluruh kelas V SD Gugus 3 Yogyakarta, yang terdiri dari 7 sekolah dengan populasi 223 siswa. Teknik pengambilan sampel dilakukan secara cluster random sampling.

Variabel Penelitian

Variabel dalam penelitian ini yaitu berupa variabel bebas (independent variables) dan variabel terikat (dependent variables). Dalam penelitian ini, yang berkedudukan sebagai variabel bebas (X) yaitu model Problem Based Learning, dan variabel terikatnya yaitu keterampilan proses sains (Y1) dan hasil belajar kognitif (Y2)

Teknik dan Instrumen Pengumpulan Data

Teknik pengumpulan data dalam penelitian ini menggunakan tes dan non tes. Tes yang digunakan dalam penelitian ini adalah tes tertulis untuk mengetahui keterampilan proses sains dan hasil belajar kognitif IPA siswa. Tes tersebut dilaksanakan pada awal pembelajaran (pretest) dan setelah siswa mengikuti proses pembelajaran (posttest). Adapun bentuk tes yang digunakan yaitu uraian. Teknik non tes yang digunakan dalam penelitian ini adalah berupa observasi untuk mendapatkan informasi berkenaan dengan keterampilan proses sains. Observasi menggunakan lembar observasi rating scale.

Validitas dan Reliabilitas Instrumen

Validitas instrumen yang dilakukan adalah validitas isi (content validity) dan validitas konstruk (contruct validity). Validitas isi dan konstruk diperoleh dengan membuat kisi-kisi instrumen dan selanjutnya digunakan teknik (experts judgment) dari dosen. Setelah instrumen mendapat-kan persetujuan dari dosen ahli dilakukan uji coba yang kemudian dianalisis menggunakan product moment. Uji reliabilitas instrumen dilakukan dengan melihat nilai koefisisen Alpha Cronbach.

Prosedur

Desain yang digunakan dalam penelitian ini adalah Pretest posttest control group design (Johnson \& Christensen, 2014, p. 340). Dalam desain ini terdapat tiga kelompok yang dipilih secara acak dan diasumsikan ketiga kelompok memiliki karakteristik yang sama (homogen). Dua kelompok diberi perlakuan (eksperimen), dan satu kelompok dijadikan sebagai kelompok kontrol. Pada ketiga kelompok diberikan pretest untuk mengetahui kemampuan awal siswa, kemudian diberikan perlakuan khusus untuk kelompok eksperimen, dan akhirnya diberikan posttest untuk mengetahui kemampuan akhir. Hasil tes dan observasi keterampilan proses sains dan hasil belajar kognitif IPA pada masing-masing kelompok juga dibandingkan atau diuji perbedaannya. Jika antara tes dan observasi tahap awal dan tahap akhir pada kelompok eksperimen menunjukkan perbedaan, maka terdapat pengaruh dari perlakuan yang diberikan.

Langkah-langkah penelitian yang dilakukan meliputi: (1) melakukan prasurvei dan mengajukan perizinan sekolah; (2) pembuatan instrumen, validasi instrumen dan uji coba instrument; (3) mengadakan koordinasi dengan guru berkaitan dengan pembelajaran dengan model Problem Based Learning; (4) melakukan pre test; (5) pemberian perlakuan pada kelompok eksperimen I dan II menggunakan model Problem Based Learning dan kelompok kontrol menggunakan model ekspositori; (6) memberi- 
Jurnal Prima Edukasia, 4 (2), Juli 2016 - 190

Ratna Hidayah, Pratiwi Pujiastuti

kan posttest pada masing-masing kelompok penelitian, dan (7) analisis data.

\section{Teknik Analisis Data}

Teknik analisis data dalam penelitian ini menggunakan statistik deskriptif dan statistika inferinsial. Analisis deskriptif digunakan untuk menyajikan data yang telah diperoleh dari hasil pre test dan post test pada keterampilan proses sains dan hasil belajar kognitif IPA pada kelompok eksperimen dan kelompok kontrol berupa (mean, standar deviasi, skor minimum dan skor maksimum) akan disajikan dalam bentuk tabel sehingga penyajian data akan mudah dipahami. Analisis inferensial digunakan digunakan untuk menguji hipotesis yang telah dibuat.

Dalam pengujian hipotesis terdapat 2 teknik analisis data yang digunakan uji $\mathrm{t}$ dan MANOVA kemudian dilanjutkan dengan uji lanjut multivariate Bonferroni. Pengujian hipotesis diawali dengan uji beda rata-rata univariat menggunakan independent t-test. Pengujian ini dilakukan untuk melihat pengaruh model Problem Based Learning terhadap keterampiulan proses sains dan hasil belajar kognitif secara terpisah. Pengujian hipotesis dilanjutkan dengan uji beda rata-rata multivariat menggunakan Multivariate Analysis of Variance (MANOVA) dengan rumus $T^{2}$ Hotteling. Pengujian hipotesis dilanjutkan dengan MANOVA, untuk melihat pengaruh model Problem Based Learning terhadap keterampilan proses sains dan hasil belajar kognitif IPA secara bersamasama. Pengujian dilanjutkan dengan uji lanjut multivariate Bonferroni untuk mengetahui model pembelajaran mana yang paling berpengaruh terhadap keterampilan proses sains dan hasil belajar kogntitif IPA.

Sebelum dilakukan uji statistik inferensial data harus memenuhi uji prasyarat analisis yaitu uji normalitas, dan uji homogenitas. Pengujian normalitas dilakukan dengan metode Kolmogrov-Sminorv. Uji normalitas digunakan untuk mengetahui data berdistribusi normal atau tidak, sedangkan uji homogenitas digunakan untuk mengetahui data berasal dari populasi yang homogen atau tidak. Uji homogenitas secara multivariat menggunakan uji Box's $M$ dan secara univariat menggunakan Levene's Test. Data dikatakan berdistribusi normal dan homogen jika nilai signifikansinya $>0,05$. Pengujian normalitas dan homogenitas mengguna-kan bantuan SPSS 16.0. for windows.

\section{Hasil Penelitian dan Pembahasan}

Analisis Deskriptif

Analisis deskriptif digunakan untuk mendeskripsikan data. Untuk mendeskripsi-kan data pretest dan posttest kelas eksperimen dan kontrol digunakan teknik statistik yang meliputi rata-rata (mean), titik tengah (median), modus, standar deviasi, varians, skor minimum dan skor maksimum. Hasil analisis deskriptif ratarata skor sebelum pelaksanaan (pretest) keterampilan proses sains siswa kelas eksperimen 1, eksperimen 2 dan kelas kontrol dapat dilihat pada Gambar 1.

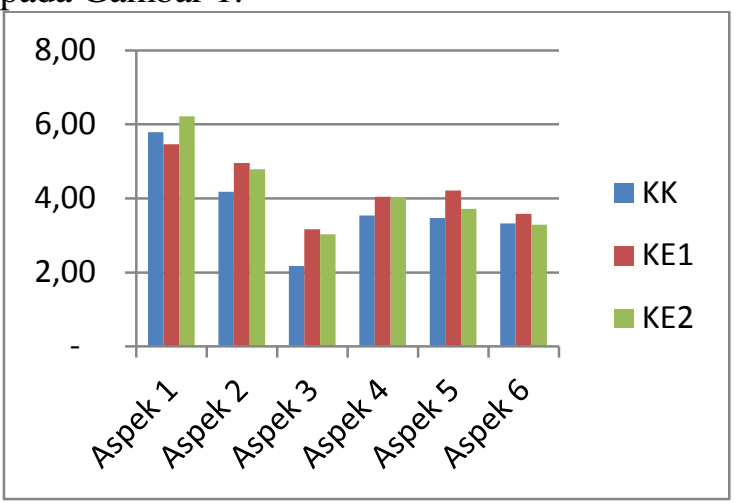

\section{Gambar 1 Diagram Hasil Pre Test Keterampilan Proses Sains}

Berdasarkan Gambar 1, skor rata-rata pretest keterampilan proses sains baik kelas eksperimen 1, kelas eksperimen 2 dan kelas kontrol terlihat hampir sama. Skor rata-rata pre tes keterampilan proses sains tiap aspek keterampilan proses sains pada kelompok eksperimen 1, 2 dan kontrol terlihat yang paling tinggi adalah aspek mengamati dan yang paling rendah adalah aspek menerapkan.

Rata-rata skor post test keterampilan proses sains siswa kelas eksperimen 1, eksperimen 2 dan kelas kontrol dapat dilihat dalam Gambar 2. 
Jurnal Prima Edukasia, 4 (2), Juli 2016 - 191

Ratna Hidayah, Pratiwi Pujiastuti

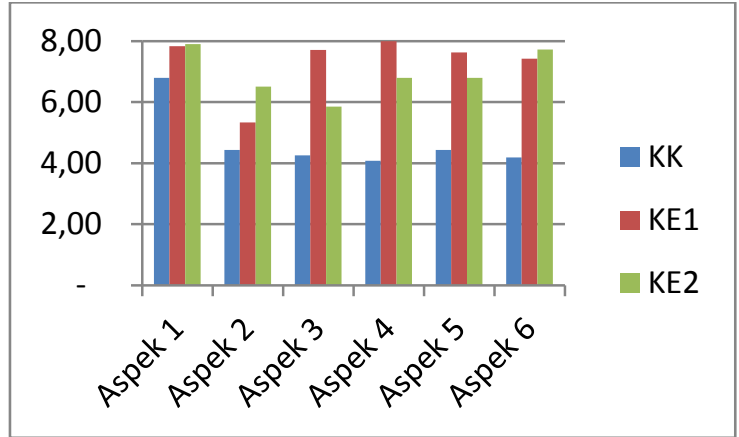

Gambar 2 Diagram Hasil Post Test Keterampilan Proses Sains

Berdasarkan Gambar 2, skor tiap aspek keterampilan proses sains pada kelompok eksperimen 1 dan 2 lebih tinggi daripada kelompok kontrol. skor rata-rata posttest aspek keterampilan proses sains yang paling tinggi pada kelompok eksperimen 1 dan 2 adalah mengkomunikasikan. Pada kelompok kontrol terlihat yang paling tinggi adalah aspek mengamati.

Rata-rata skor hasil observasi keterampilan proses sains dapat dilhat pada Gambar 3 .

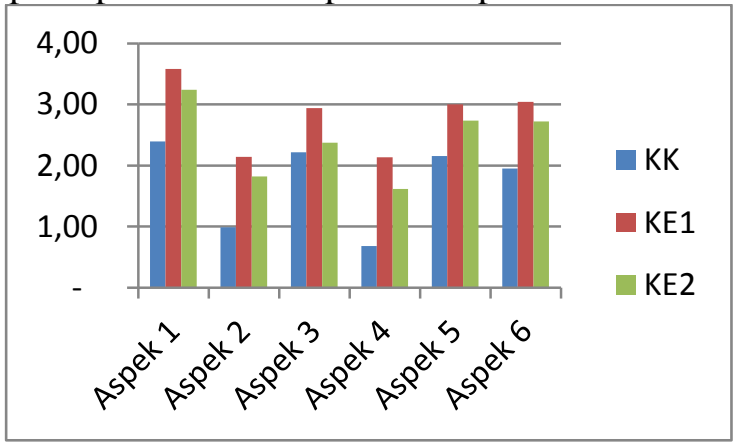

Gambar 3 Diagram Skor Hasil Observasi

Keterampilan Proses Sains

Berdasarkan gambar 3, rata-rata skor tiap aspek keterampilan proses sains pada kelompok eksperimen 1 dan 2 lebih tinggi daripada kelompok kontrol. Pada aspek mengkomunikasikan terlihat rerata skor hasil observasi paling tinggi.

Dengan demikian dapat disimpulkan bahwa model Problem Based Learning pada kelas eksperimen lebih memberikan pengaruh yang positif pada keterampilan proses sains siswa kelas V SD Gugus 3 Kotagede.

Rata- rata skor pretest hasil belajar kognitif IPA dapat dilhat pada diagram berikut

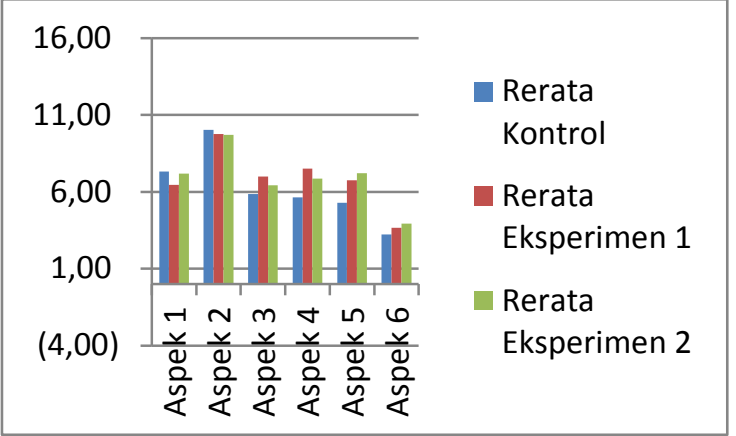

\section{Gambar 4 Diagram Skor Pretest Hasil Belajar Kognitif}

Berdasarkan Gambar 4 diketahui bahwa rata- rata skor pretest hasil belajar kognitif IPA pada kelas eksperimen 1, kelas eksperimen 2, dan kelas kontrol terlihat aspek memahami adalah yang paling tinggi kemudian aspek menganalisis. Sementara aspek mencipta adalah yang paling rendah.

Rata- rata skor posttest hasil belajar kognitif IPA siswa kelas eksperimen 1, eksperimen 2 dan kelas kontrol dapat dilihat dalam gambar 5.

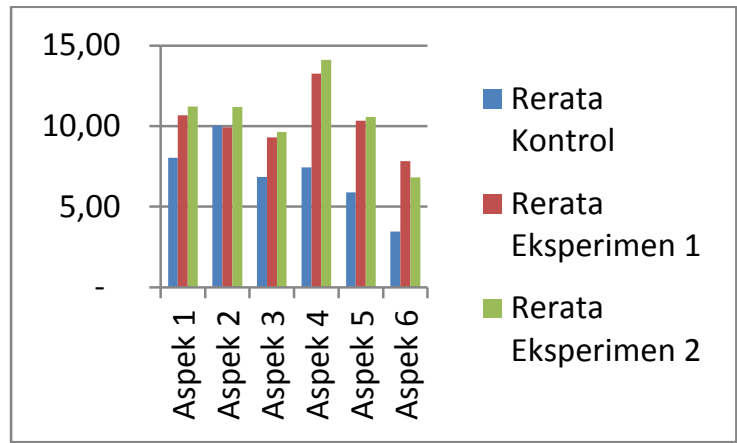

Gambar 5 Diagram Skor Posttest

Hasil Belajar Kognitif

Berdasarkan Gambar 5, rata-rata skor posttest tiap aspek hasil belajar kognitif IPA pada kelompok eksperimen 1 dan 2 lebih tinggi daripada kelompok kontrol. Pada gambar terlihat aspek mengkomunikasikan adalah yang paling Sementara aspek mencipta adalah yang paling rendah.

\section{Hasil Uji Prasyarat Analisis}

Sebelum dilakukan pengujian hipotesis, uji prasyarat yang harus dipenuhi adalah uji normalitas dan homogenitas untuk masing-masing kelompok. Berikut disajikan hasil analisis uji normalitas dan homogenitas. Hasil uji normalitas dapat dilihat pada Tabel 1 . 
Jurnal Prima Edukasia, 4 (2), Juli 2016 - 192

Ratna Hidayah, Pratiwi Pujiastuti

Tabel 1. Hasil Uji Normalitas

\begin{tabular}{lccc}
\hline \multirow{2}{*}{ Variabel } & \multicolumn{3}{c}{ Signifikansi Kolmogrov-Smirnov } \\
\cline { 2 - 4 } & Eks 1 & Eks 2 & KK \\
\hline Pre test KPS & 0,790 & 0,209 & 0,905 \\
Post test KPS & 0,406 & 0,159 & 0,627 \\
Pre test $\mathrm{HBK}$ & 0,887 & 0,053 & 0,784 \\
Post test $\mathrm{HBK}$ & 0,792 & 0,052 & 0,563 \\
\hline
\end{tabular}

Keterangan:

KE 1 = kelompok eksperimen 1

KE 2 = kelompok eksperimen 2

KK $=$ kelompok kontrol

KPS = Keterampilan Proses Sains

HBK = Hasil Belajar Kognitif

Tabel 1 menunjukkan bahwa data keterampilan proses sains dan hasil belajar kognitif IPA siswa pada kelas eksperimen 1, eksperimen 2 dan kontrol mempunyai nilai signifikansi lebih besar dari 0,05 yang berarti data berdistribusi normal.

Tabel 2. Hasil Uji Homogenitas Box M

\begin{tabular}{cccc}
\hline Variabel & Box's M & Sig & Ket \\
\hline Pretest & 3,968 & 0,701 & Homogen \\
Posttest & 8,866 & 0,202 & Homogen \\
\hline
\end{tabular}

Berdasarkan Tabel 2 diketahui bahwa hasil analisis uji homogenitas secara multivariate pretest dan posttest untuk kelas eksperimen 1, eksperimen 2 dan kelas kontrol menunjukkan nilai signifikansi > 0,05, yang berarti homogen.

Tabel 3. Hasil Uji Homogenitas Univariat

\begin{tabular}{ccccc}
\hline \multicolumn{2}{c}{ Variabel } & F & Sig & Ket \\
\hline \multirow{2}{*}{ Pre test } & KPS & 0.427 & 0.654 & Homogen \\
Post & HBK & 1.802 & 0.172 & Homogen \\
test & HBK & 0.546 & 0.582 & Homogen \\
\hline
\end{tabular}

Tabel 3 menunjukkan bahwa hasil analisis uji homogenitas secara univariat pretest dan posttest untuk kelas eksperimen 1, eksperimen 2 dan kelas kontrol memiliki nilai signifikansi $>0,05$, yang berarti homogen.

Hasil Uji Hipotesis

Setelah hasil uji prasyarat analisis normalitas dan homogenitas telah terpenuhi, maka analisis yang dilakukan adalah uji hipotesis.

Uji Univariat

Tabel 4. Hasil Uji dengan Independent Sample

$T$-test Postest Kelas Eksperimen dan Kelas Kontrol

Kelas $\quad$ Var $\quad \mathbf{t}_{\text {hitung }} \quad$ Sig $\quad$ Ket.

\begin{tabular}{|c|c|c|c|c|}
\hline Eks $1 \&$ & KPS & 15,407 & 0,000 & $\begin{array}{c}\text { Ada } \\
\text { perbedaan }\end{array}$ \\
\hline Kontrol & HBK & 12,103 & 0,000 & $\begin{array}{c}\text { Ada } \\
\text { perbedaan }\end{array}$ \\
\hline Eks $2 \&$ & KPS & 13,515 & 0,000 & $\begin{array}{c}\text { Ada } \\
\text { perbedaan }\end{array}$ \\
\hline Kontrol & HBK & 11,831 & 0,000 & $\begin{array}{c}\text { Ada } \\
\text { perbedaan }\end{array}$ \\
\hline
\end{tabular}

Tabel 4 menunjukkan bahwa nilai signifikansinya $<0,025$. Sehingga, dapat disimpulkan bahwa; (1) Problem Based Learning lebih memberikan pengaruh yang positif dan signifikan terhadap keterampilan proses sains pada siswa kelas V SD Gugus 3 Kotagede Yogyakarta; (2) Problem Based Learning lebih memberikan pengaruh yang positif dan signifikan terhadap hasil belajar kognitif IPA pada siswa kelas V SD se-gugus 3 Kotagede Yogyakarta.

Uji Multivariat

Tabel 5. Hasil Penghitungan dengan Hotteling's Trace Manova

\begin{tabular}{cccc}
\hline Effect & Test & Sig & Ket \\
\hline $\begin{array}{c}\text { Hotteling's } \\
\text { Trace }\end{array}$ & Pretest & 0,118 & $\begin{array}{c}\text { Tidak ada } \\
\text { perbedaan } \\
\text { Ada perbedaan }\end{array}$ \\
\hline
\end{tabular}

Tabel 5 menunjukkan bahwa nilai signifikansi untuk pretest menunjukkan 0,030 > 0,05 berarti bahwa kemampuan awal siswa antara kelas eksperimen dan kelas kontrol tidak menunjukkan adanya perbedaan. Sedangkan untuk posttest, nilai signifikansi yang diperoleh adalah $0,000<0,05$ berarti bahwa terdapat perbedaan rata-rata kemampuan akhir kelas kontrol dan kelas eksperimen. Dari hasil penghitungan menunjukkan bahwa terdapat perbedaan antara kelas eksperimen dan kelas kontrol, sehingga dapat disimpulkan bahwa model Problem Based Learning memberikan pengaruh yang positif dan signifikan terhadap keterampilan proses sains dan hasil belajar kognitif IPA pada siswa kelas V SD Gugus 3 Kotagede Yogyakarta.

Tabel 6. Hasil Uji Bonferroni

\begin{tabular}{cccc}
\hline \multirow{2}{*}{ Variabel Terikat } & \multicolumn{2}{c}{ Kelompok } & \multirow{2}{*}{ Sig } \\
& Kelas & Kelas & \\
\hline \multirow{2}{*}{ Post test KPS } & \multirow{2}{*}{ KK } & KE2 & 0,000 \\
& & KE1 & 0,000 \\
\multirow{2}{*}{ Post test HBK } & \multirow{2}{*}{ KK } & KE2 & 0,000 \\
& & KE1 & 0,000 \\
\hline
\end{tabular}


Jurnal Prima Edukasia, 4 (2), Juli 2016 - 193

Ratna Hidayah, Pratiwi Pujiastuti

Tabel 6 menunjukkan bahwa nilai signifikansi kelas kontrol terhadap kelas eksperimen 1 dan 2 untuk post test keterampilan proses sains menunjukkan signifikansi $0,000<0,05$ berarti bahwa keterampilan proses sains dengan model Problem Based Learning di kelas eksperimen lebih tinggi daripada keterampilan proses sains dengan ekspositori di kelas kontrol. Sedangkan nilai signifikansi kelas kontrol terhadap kelas eksperimen 1 dan 2 untuk post test hasil belajar kognitif IPA menunjukkan signifikansi $0,000<0,05$ berarti bahwa hasil belajar kognitif IPA pada pembelajaran IPA dengan model Problem Based Learning di kelas eksperimen lebih tinggi daripada hasil belajar kognitif IPA pada pembelajaran IPA dengan ekspositori di kelas kontrol.

Pembahasan

\section{Pengaruh Model Problem Based Learning terhadap Keterampilan Proses Sains}

Hasil penelitian menunjukkan bahwa model problem based learning memberikan pengaruh yang positif dan signifikan terhadap keterampilan proses sains pada siswa kelas $\mathrm{V}$ SD se gugus 3 Kotagede. Hal ini dapat terjadi karena keterampilan proses sains dilatihkan dalam problem based learning. Senada dengan hasil penelitian Handika \& Wangid (2013, p.92) yang menunjukan bahwa pembelajaran berbasis masalah memberikan pengaruh yang lebih baik dan secara signifikan meningkatkan keterampilan proses sains siswa sekolah dasar.

Hasil analisis data sebelum pelaksanaan (pre test) menunjukkan aspek mengamati paling tinggi dan aspek menerapkan paling rendah. Hal ini dapat terjadi karena pembelajaran yang berlangsung masih menggunakan ekspositori. Pada pembelajaran menggunakan ekspositori siswa kurang mendapat kesempatan untuk aktif dalam kegiatan belajar karena semua langkah pembelajaran terpusat pada guru. Kegiatan percobaan pun tidak dilakukan dalam pembelajaran. Metode ceramah dan mengamati suatu gambar saja yang paling sering digunakan guru dalam pembelajaran. Hal ini lah yang menyebabkan aspek menerapkan siswa masih rendah dan aspek mengamti memiliki rata- rata skor paling tinggi.

Hasil post test menunjukkan bahwa aspek mengkomunikasikan dan menerapkan pada kelas eksperimen 1 dan 2 mengalami peningkatan paling tinggi. Kemampuan akhir aspek menerapkan dan mengkomunikasikan pada kelas eksperimen 1 dan 2 tergolong pada kategori sangat tinggi sedangkan kontrol masih pada kategori tinggi. Hasil observasi juga menunjukkan hasil yang sama bahwa aspek mengkomunikasikan dan menerapkan adalah yang paling tinggi. Hal tersebut bisa terjadi karena dalam problem based learning menggunakan masalah yang ada dalam kehidupan nyata sebagai sarana bagi siswa untuk memperoleh keterampilan pemecahan masalah dan memperoleh pengetahuan. Siswa aktif dalam proses belajar melalui pengalaman atau belajar dari pengalaman. Peran guru dalam problem based learning bertindak sebagai fasilitator. Holil dalam Handika \& Wangid (2013, p.87) menyatakan bahwa PBM dalam pembelajaran sains merupakan salah satu pembelajaran yang cukup menarik dikarenakan (1) PBM mengajak siswa untuk menyelesaikan kasus atau permasalahan yang berkaitan dengan sains; (2) meningkatkan minat diskusi antarpeserta didik dan mendo-rong kegiatan belajar; (3) membantu siswa mengkonstruksi pengetahuannya tentang dunia di sekitarnya dan mambantu meletakkan pon-dasi pengetahuan awal mereka sebelum berlanjut ke pengetahuan yang lebih kompleks.

Guru tidak menyampaikan materi dalam jumlah banyak tetapi guru menghadirkan permasalahan nyata berkaitan dengan peristiwa alam pernah terjadi. Dari permasalahan nyata tersebut diangkat ke dalam sebuah percobaan. Dalam percobaan siswa terlibat dalam menganalisis masalah dan menyelidiki untuk menemukan solusi. Guru membuat kelompokkelompok kecil sehingga dapat siswa dapat bekerja sama dalam lingkungan belajarnya. Melalui kelompok tersebut siswa dapat mengidentifikasi, menganalisis dan menemukan solusi untuk mengatasi peristiwa alam. Untuk mendukung kegiatan tersebut, guru tentunya menyedikan alat percobaan. Kegiatan terakhir yang harus dilakukan siswa yaitu membuat laporan dan mempresentasikan. Kegiatan percobaan dan mempresentasikan tersebut yang dapat mendorong kemampuan menerapkan dan mengkomunikasikan siswa sehingga kedua aspek tersebut mengalami peningkatan skor yang tinggi. Adanya kegiatan diskusi dan kerjasama tentunya dapat meningkatkan kemampuan komunikasi sosial. Seperti yang 
Jurnal Prima Edukasia, 4 (2), Juli 2016 - 194

Ratna Hidayah, Pratiwi Pujiastuti

diungkapkan Arends (2008, p.43) bahwa problem based learning berpengaruh meningkatkan keterampilan komunikasi dan keterampilan sosial yang diperlukan untuk kerjasama dan kerja tim. Arends juga mengungkapkan bahwa problem based learning berpengaruh positif terhadap keterampilan penyelidikan dan keterampilan mengatasi masalah. Siswa tidak hanya mampu melakukan penyelidikan tetapi juga mampu menerapkan keterampilannya dalam kehidupan sehari- hari terutama dalam menamukan solusi dari permaslahn yang dihadapi dalam kehidupan nyata.

Problem based learning selain untuk mendorong siswa untuk mempelajari perannya melalui masalah nyata yang ditunjukan dan mendorong untuk menjadi siswa mandiri. Sesuai dengan yang diungkapkan Arends (2008, p.43) yaitu Problem based learning berpengaruh terhadap keterampilan untuk belajar secara mandiri. Artinya siswa lebih aktif dan dapat belajar secara mandiri melalui problem based learning.

Pelaksanaan dalam problem based learning bersifat mendukung penyelidikan dan kebebasan berfikir. Adanya proses bekerjasama dalam problem based learning membuat siswa menyatukan pendapat untuk memahami materi pembelajaran melalui kegiatan penyelidikan sehingga siswa mendapatkan pengetahuan lalu menyampaikan hasil. Hal tersebut tentunya berpengaruh terhadap keterampilan proses siswa dalam aspek menerapkan dan mengkomunikasikan siswa. Chunta and Katrancha (2010) dalam jurnalnya menyatakan bahwa problem based learning, digambarkan sebagai strategi mengajar aktif, menyediakan sebuah kerangka kerja untuk pengembangan pembelajaran mandiri, evaluasi diri, komunikasi yang interpersonal, berpikir kritis, dan akses dan pengambilan informasi. Dalam suatu website juga menyatakan "...PBL can help students develop communication, reasoning and critical thingking skill..." (http:dept.washington.edu/cidrweb). Beberapa kelebihan problem based learning menurut Westwood (2008, p.31) antara lain memberdayakan siswa untuk mengidentifikasi, menemukan dan menggunakan sumber daya yang sesuai; aktif terlibat dalam mengintegrasikan informasi dan keterampilan dari berbagai disiplin ilmu; pengetahuan dan strategi memperoleh ilmu cenderung akan disimpan dan ditransfer ke situasi belajar lainnya dan meningkatkan keterampilan komunikasi dan keterampilan sosial yang diperlukan untuk kerjasama dan kerja tim. Senada dengan hasil penelitian Sudarman (2007, p.73) bahwa pembelajaran berbasis masalah dapat membantu kemampuan berpikir, pemecahan masalah dan keterampilan intelektual dan belajar menjadi pembelajar yang otonom serta dapat mendorong kerja sama.

\section{Pengaruh Model Problem Based Learning} terhadap Hasil Belajar Kognitif IPA

Hasil penelitian telah membuktikan bahwa model Problem Based Learning secara positif dan signifikan memberikan pengaruh yang berbeda terhadap hasil belajar kognitif IPA, antara siswa yang mengikuti pembelajaran dengan Problem Based Learning dan siswa yang mengikuti model pembelajaran ekspositori.

Pelaksanaan model problem based learning dalam menyampaikan materi pelajaran selalu diawali dengan pemberian masalah nyata kemudian dari permasalahan nyata tersebut diangkat ke dalam sebuah percobaan. Problem based learning memberikan kesempatan kepada siswa untuk belajar mandiri dan memperoleh pengalaman. Problem based learning memiliki karakteristik yang khas yaitu menggunakan masalah dunia nyata sebagai konteks belajar bagi siswa untuk belajar tentang berfikir kritis dan keterampilan memecahkan masalah, serta untuk memperoleh pengetahuan dan konsep esensial dari materi pelajaran dengan demikian siswa terbiasa melakukan hal yang dengan sistematis dan urut sehingga kemampuan menganalisis siswa dapat meningkat.

Pada proses pembelajaran dengan menggunakan model problem based learning memberikan kesempatan siswa belajar melalui pengalaman dengan melakukan percobaan. Konsep akan tersimpan lebih lama dalam memori apabila siswa tidak hanya melihat dan mendengar tetapi juga melakukan. Siswa akan lebih mudah mengingat materi yang diajarkan. Dengan demikian, melalui problem based learning dapat meningkatkan kemampuan siswa dalam mengingat. Hal ini dipertegas dalam beberapa penelitian, yaitu penelitian Handika \& Wangid (2013, p. 87) bahwa 
Jurnal Prima Edukasia, 4 (2), Juli 2016 - 195

Ratna Hidayah, Pratiwi Pujiastuti

pembelajaran berbasis masalah dalam mata pelajaran sains atau IPA merupakan salah satu pembelajaran yang cukup menarik dikarenakan (1) Pembelajaran berbasis masalah mengajak siswa untuk menyelesaikan kasus atau permasalahan yang berkaitan dengan sains; (2) meningkatkan minat diskusi antar siswa dan mendorong kegiatan belajar; (3) membantu siswa mengkonstruksi pengetahuannya tentang dunia di sekitarnya dan mambantu meletakkan pondasi pengetahuan awal mereka sebelum berlanjut ke pengetahuan yang lebih kompleks. Hasil penelitian yang telah dilakukan Wulandari \& Surjono (2013, p. 189) menunjukkan bahwa hasil belajar siswa yang diajar dengan metode $P B L$ lebih tinggi dibandingkan dengan siswa yang diajar dengan metode pembelajaran demonstrasi. Sejalan pula dengan kesimpulan Choon, G., Koh, H., Khoo., H.E., Wong., M. L., et.al (2008) yang menyatakan dalam pelaksanaan problem based learning di sekolah kesehatan, problem based learning memberi dampak positif terhadap kompetensi dokter dalam dimensi social dan kognitif.

\section{Pengaruh Model Problem Based Learning terhadap Keterampilan Proses Sains dan Hasil Belajar Kognitif.}

Hasil penelitian membuktikan bahwa model problem based learning memberikan pengaruh yang positif dan signifikan terhadap keterampilan proses sains dan hasil belajar kognitif IPA pada siswa kelas V SD se-gugus 3 Kotagede Yogyakarta. Hal tersebut karena model problem based learning dengan menggunakan permasalahan nyata sebagai titik awal pembelajaran. Problem based learning, berfokus pada penyajian suatu permasalahan (nyata-stimulus). Permasalahan menjadi fokus, stimulus, dan pemandu proses belajar, sementara guru menjadi fasilitator dan pembimbing. Siswa mendapatkan keterampilan dan pengetahuan yang dibutuhkan dalam proses usaha penemuan solusi atas masalah itu. Dalam proses ini siswa bertanggung jawab atas pembelajaran mereka sendiri karena keterampilan itu yang siswa butuhkan. Siswa menerapkan apa yang telah diketahui, menemukan apa yang perlu diketahui, dan belajar bagaimana mendapatkan informasi yang dibutuhkan lewat berbagai sumber serta menyampaikan kepada umum tentang hasil temuannya.

Proses pemecahan atau penemuan solusi suatu masalah dalam problem based learning menggunakan langkah-langkah metode ilmiah. Dengan demikian siswa belajar secara sistematis dan terencana. Oleh sebab itu, penggunaan problem based learning dapat memberikan pengalaman belajar melakukan kerja ilmiah yang sangat baik kepada siswa.

Problem based learning memberi kesempatan siswa untuk melakukan percobaan dengan mengalami dan membuktikan sendiri suatu pertanyaan atau hipotesis sehingga membuat siswa kreatif dan mandiri baik secara individu maupun kelompok untuk menerapkan serta mengembangkan keterampilan sains siswa yang dimilikinya.

Model problem based learning tidak hanya sekedar menerima informasi dari guru saja. Problem based learning ini memberi kesempatan siswa untuk merencakan dan berpartisipasi dalam menginvestigasi suatu masalah. Kegiatan menempatkan siswa pada posisi mengajukan, mengamati, mengklasifikasikan, menerapkan, memprediksi, menafsirkan, dan mengkomunikasikan. Karakteristik problem based learning lebih mengacu pada aliran pendidikan kontruktivistik, dimana belajar merupakan proses aktif dari pembelajaran untuk membangun pengetahuan. Proses aktif yang dimaksud tidak hanya bersifat secara mental tetapi juga secara fisik. Seperti halnya yang diungkapkan Mujis dan Reynolds (2008, p.194) bahwa pengajaran kontruktivistik dapat membantu pengembangan keterampilan berpikir melalui gaya pengajaran openeded berbasis masalah yang digunakan guru. Problem based learning dapat memberikan pengaruh terhadap keterampilan dan hasil belajar sesuai dengan beberapa kelebihan problem based learning yang diungkapkan Westwood (2008, p. 31) antara lain memberdayakan siswa untuk mengidentifikasi, menemukan dan menggunakan sumber daya yang sesuai; aktif terlibat dalam mengintegrasikan informasi dan keterampilan dari berbagai disiplin ilmu; pengetahuan dan strategi memperoleh ilmu cenderung akan disimpan dan ditransfer ke situasi belajar lainnya dan meningkatkan keterampilan komunikasi dan keterampilan sosial yang diperlukan untuk kerjasama dan kerja tim.Hal 
Jurnal Prima Edukasia, 4 (2), Juli 2016 - 196

Ratna Hidayah, Pratiwi Pujiastuti

tersebut menandakan bahawa problem based learning tidak hanya berpengaruh terhadap keterampilan tetapi juga dapat meningkatkan pengetahuan siswa. Sebagaimana yang diungkapkan oleh Christensen \& Martin (dalam Anindyta, 2014, p. 221), kegiatan pemecahan masalah tidak hanya dapat mengembangkan keterampilan berpikir kritis, namun juga dapat memperdalam pemahaman siswa terhadap konsep yang dipelajari. Ketika siswa dilibatkan dalam memecahkan masalah, siswa merasa memiliki peranan dalam usaha untuk menemukan solusi atas masalah yang ada. Melalui pemahaman tersebut, tumbuh kesadaran siswa untuk melakukan tindakan secara nyata dalam memecahkan masalah yang diberikan guru. Hal ini dipertegas dengan hasil penelitian Bungel (2014, p. 53) bahwa bahwa model pembelajaran problem based learning dengan lima tahapan yaitu tahap konsep dasar, pendefinisian masalah, belajar mandiri, belajar kelompok dan penilaian sehingga dapat meningkatkan hasil belajar siswa SMP. Hasil penelitian Haryono (dalam Sole, 2013, p. 40) juga menyimpulkan bahwa model pembelajaran berbasis keterampilan proses IPA terbukti cukup efektif dalam meningkatkan kemampuan proses IPA siswa sekaligus pencapaian hasil belajarnya secara keseluruhan.

\section{Simpulan dan Saran}

Simpulan

Berdasarkan hasil penelitian dan pembahasan di atas maka dapat disimpulkan bahwa bahwa (1) Model problem based learning memberikan pengaruh yang positif dan signifikan terhadap keterampilan proses sains pada siswa kelas V SD Gugus 3 Kotagede; (2) Model problem based learning memberikan pengaruh yang positif dan signifikan terhadap hasil belajar kognitif IPA pada siswa kelas V SD Gugus 3 Kotagede; (3) Model problem based learning memberikan pengaruh yang positif dan signifikan terhadap keterampilan proses sains dan hasil belajar kognitif pada siswa kelas V SD Gugus 3 Kotagede.

Saran

Saran penelitian mengenai penggunaan model Problem Based Learning terhadap keterampilan proses sains dan hasil belajar kognitif guru adalah pembelajaran IPA tidak hanya dilakukan dengan pembelajaran ekspositori, tetapi guru dapat memilih model pembelajaran yang memungkinkan siswa berpartisipasi aktif dan terlibat langsung terhadap objek yang diamati sehingga pembelajaran berpusat pada siswa. Guru dapat menerapkan model problem based learning pada pembelajaran yang melibatkan permasalahan sehari-hari, tidak hanya pada mata pelajaran IPA, namun juga pada mata pelajaran lainnya.

\section{Daftar Pustaka}

Anindyta, P., \& Suwarjo, S. (2014). Pengaruh problem based learning terhadap keterampilan berpikir kritis dan regulasi diri siswa kelas V. Jurnal Prima Edukasia, 2(2), 209-222. doi:http://dx.doi.org/10.21831/jpe.v2i2. 2720

Arends, R. I. (2008). Belajar untuk mengajar (Terjemahan Helly Prayitno Soetjipto \& Sri Mulyantini Soetjito). New York: Me Craw Hill (buku asli terbitan tahun 2007).

Bungel, M. F. (2014). Penerapan Model Pembelajaran Problem Based Learning untuk Meningkatkan Hasil Belajar Siswa Kelas VII SMP Negeri 4 Palu. Jurnal Elektronik Pendidikan Matematika Tadulako, Volume 2 Nomor. Diakses pada tanggal 5 Mei 2015 pukul 19.20 WIB, dari. http://jurnal.untad.ac.id/jurnal/index.ph p/JEPMT/article/download/3230/2285.

Choon, G., Koh, H., Khoo., H.E., Wong., M. L., et.al (2008). The effects of problembased learning during medical school on Physician competency: a systematic review. Canadian Medical Association Journal, 178 (1), 34-41. Diakses tanggal 8 Mei 2015 pukul 18.40 WIB dari

http://www.cmaj.ca/content/178/1/34.

Chunta, K.S., Katrancha., \& Elizabeth D. (2010). Using problem-based learning in staff development: strategies for teaching registered nurses and new graduate nurses. The Journal of Continuing Education in Nursing 41.12 (Dec 2010): 557-64. Diakses tanggal 14 Juli 2014 pukul 14.53 WIB dari 
Jurnal Prima Edukasia, 4 (2), Juli 2016 - 197

Ratna Hidayah, Pratiwi Pujiastuti

http://search.proquest.com/docview/13 4290 ? accountid $=31324$.

Handika, I., \& Wangid, M. (2013). Pengaruh pembelajaran berbasis masalah terhadap penguasaan konsep dan keterampilan proses sains siswa kelas V. Jurnal Prima Edukasia, 1(1), 85-93. doi:http://dx.doi.org/10.21831/jpe.v1i1. 2320

Johnson, Burke \& Christensen, Larry. (2012). Educational Research: Quantitative, qualitative, and mixed approaches $\left(4^{\text {th }}\right.$ Edition). London: SAGE Publication Ltd.

Massa, N.M. (2008). Problem based learning $(P B L)$. A real-word antidote to the standars and testing regime. Diambil pada tanggal 10 Maret 2015 pukul 09.15 WIB, dari http://www.nebhe.org/wpcontent/uploads/2008-Winter_ Massa.pdf.

Mujis, D \& Reynolds, D. (2008). Effective teaching. (Terjemahan Helly Prayitno Soetjipto \& Sri Muyantini Soetjito). London: Sage Publications. (Buku asli diterbitkan tahun 2008).
Sole, F., \& Wilujeng, I. (2013). Pengaruh implementasi the 4-E learning cycle terhadap pengetahuan, keterampilan proses dasar, dan sikap ilmiah IPA siswa SDK Kererobbo. Jurnal Prima Edukasia, $\quad$ 1(1), 43-50. doi:http://dx.doi.org/10.21831/jpe.v1i1. 2315

Sudarman. (2007). Problem basic learning: Suatu model pembelajaran untuk mengembangkan dan meningkatkan kemampuan memecahkan masalah. Jurnal Pendidikan Inovatif. Vol. 2 no 2. Diakses pada tanggal 5 Mei 2015 pukul 18.40 WIB, dari http://www.physicsmaster.orgfree.com/ Artikel\% 20\&\%20Jurnal/Wawasan\%20Pendidika n/PBL\%20Model.pdf.

Wulandari, B., \& Surjono, H. (2013). Pengaruh problem-based learning terhadap hasil belajar ditinjau dari motivasi belajar PLC di SMK. Jurnal Pendidikan Vokasi, 3(2). Retrieved fromhttp://journal.uny.ac.id/index.php/j pv/article/view/1600

Westwood, P. (2008). What teachers need to know about teaching methods. Camberwell, VIC: Acer Press. 